\title{
Trade policy and firm performance: introduction to the special section
}

\author{
Mauro Caselli ${ }^{1} \cdot$ Andrea Fracasso $^{1} \cdot$ Stefano Schiavo $^{1,2}$
}

Published online: 21 January 2021

(c) Springer Nature Switzerland AG 2021

Recent years have witnessed a resurgence of trade protectionism, either vocally used as an electoral tool or more discretely implemented within WTO rules. On the one hand, the US-China trade war that has erupted in 2018 over steel and aluminium has often made the news, helped by the size of the two contenders. The reciprocal, unilateral imposition of tariffs has spilled over to other products, from agricultural commodities to 5G technology, and other countries as well, with the US threatening to sanction automotive imports from the EU and Japan on national security grounds. On the other hand, a less vocal yet more pervasive trend has started in the aftermath of the 2007-2008 financial crisis, with several countries imposing discriminatory measures to favour domestic firms (Evenett 2019), and has gained prominence in the context of the fight against the COVID-19 pandemic, when many countries have resorted to trade restrictions ranging from export licenses to outright export bans (Pauwelyn 2020) in the attempt to secure domestic availability of necessary goods such as protective garments, medical equipment, or simply food.

The context where these events take place is one where the rule-based system that has governed international trade flows since the Bretton Wood era, built around the GATT and the WTO, is in jeopardy. Since the mid-2000, the lack of progress in the Doha round of multilateral negotiations signalled the difficulties associated with each country holding a de facto veto power. Moreover, the WTO dispute settlement crisis that erupted in 2019, with the Appellate Body unable to function for a lack of

\footnotetext{
This special section originates from the 14th meeting of the International Study Group on Export and Productivity (ISGEP), held in Trento in September 2019. The guest editors would like to thank Chiara Tomasi and Min Zhu, who contributed to the organisation of the workshop.
}

Mauro Caselli

mauro.caselli@unitn.it

Andrea Fracasso

andrea.fracasso@unitn.it

Stefano Schiavo

stefano.schiavo@unitn.it

1 University of Trento, Trento, Italy

2 OFCE SciencesPo, Paris, France 
new appointments to replace members whose terms had expired (new appointments being blocked mainly by the United States), has certified the dire state of the institution that is supposed to govern international trade (Bown and Keynes 2020).

Despite these difficulties and a progressive shift from multilateralism to a tangle of bilateral and plurilateral trade agreements, in the first decade of the 21th century, trade liberalization had continued its march, spreading to emerging economies traditionally less integrated into world markets and leading to what Richard Baldwin (2016) has labelled "The Great Convergence". The virtues of free trade appeared so entrenched in the public discourse that in the aftermath of the financial crisis of 2007-2008 countries avoided blatant protectionism as the world experienced in the 1930s. Yet, this period's successes saw the seeds of the current demise.

To start with, the integration of China into global trade since its accession to the WTO in 2002 and its rapid rise as a production hub and export powerhouse has been felt across the world. While the benefits of low prices, together with the prospect of a large number of potential consumers, seemed overwhelmingly positive at first, over time fears about job losses and unfair competition started to surface, including in voting booths (Colantone and Stanig 2018a, b; Caselli et al. 2020a, b; Autor et al. 2020). The sharp contraction in economic activity brought about by the Great Recession reinforced this trend and several countries added strings to their stimulus plans aimed at favouring domestic firms over foreign competitors. The outright protectionism we have been witnessing during the last couple of years was just one step away. In between, lies the strategic use of administered protection and temporary trade barriers allowed by WTO rules, such as anti-dumping (AD) duties that often represent nothing more than "a clever form of protectionism" in the words of Thomas Prusa (2005). To this, one may also consider the growingly abusive employment of national security arguments to justify trade restrictions (Cohen 2020; Prazeres 2020).

The new US Administration led by President Biden is expected to adopt a less confrontational approach towards foreign competitors, support a reformed WTO and aim at better trade relationships with the countries recently joining the Regional Comprehensive Economic Partnership (González et al. 2020). This might entail that the pendulum will gradually sway back to more trade openness, but new restrictive measures will likely go hand in hand with the removal of existing ones. Tariff and non-tariff barriers will thus continue to impact significantly on international trade patterns.

The impact of trade barriers on domestic firms and workers is often less obvious than it appears. In a world where production no longer occurs in a single location, but rather is split into separate steps taking place in distance countries, intermediate products travel back and forth along complex value chains, crossing borders multiple times. As such, not only do imports represent as much a source of domestic competitiveness (Bloom et al. 2016; Caselli 2018) as they may represent a threat (Iacovone et al. 2013; Utar 2014; Caselli and Schiavo 2020; Caselli et al. 2021), but local firms may end up being negatively affected by the very trade barriers that are supposed to protect them from foreign competition (Bown, 2020). The news that in September 2020 thousands of US companies were suing the Trump administration over its China tariffs makes this point very clear. Given the large degree 
of heterogeneity that characterizes firms within narrowly-defined sectors, and even products within the same firm, the impact of trade policy is likely to be very different across firms (Amiti et al. 2019, 2020), and the basic notion that tariffs protect domestic jobs needs to be updated.

Despite their importance for the performance of firms, product and labour markets, and the overall economy, the way trade restrictions shape production and export activities remains poorly understood. Yet, the issue is critical for both economists and policymakers in order to design effective policies and provide the right incentives to invest in technology adoption, productivity improvements and even to address global issues such as climate change and social rights. Indeed, one of the most interesting proposals for a global carbon tax features a tariff levied on goods imported from countries unwilling to join the international efforts to fight climate change (Nordhaus 2015). In a similar vein, several countries, including those belonging to the EU, have proposed to address the lack of social rights by including and implementing more stringently social clauses in their trade agreements (von der Leyen 2019; Harrison et al. 2019). In such cases, and in many others as well, it becomes imperative to have a clear view of the heterogeneous impact of trade barriers on economic sectors, firms and workers.

The papers contained in this Special Section shed new light on the topic, by combining detailed information on trade policy with firm- and worker-level data that enable the authors to examine the different channels through which trade barriers, in advanced, emerging and developing countries, exert heterogeneous effects on countries, sectors, firms and workers.

Schiavo, Tomasi and Zhu ("Anti-dumping activities against China: patterns and effects") examine the uses (and abuses) of AD duties in the period 1980-2015, with a focus on measures imposed by the European Union and the United States. They confirm the growing popularity of such trade remedies (even among emerging economies), the concentration of duties in few sectors and the increasing role of China as a target country. Paradoxically, AD measures are increasingly targeting intermediate goods, whose share in global trade has dramatically grown and now accounts for more than half of global trade, although they are particularly important for the competitiveness of domestic firms. In addition, using transaction-level information on Chinese exporting firms, they show that AD measures reduce exports, with an impact on both the extensive and the intensive margin of trade. Moreover, the export prices of targeted products tend to rise marginally, so that the fall in export quantities is particularly strong.

Fusacchia, Antimiani and Salvatici (“An assessment of import tariff costs for Italian exporting firms") provide a theory-based assessment of the costs of trade protection for Italian exporters. Starting from the observation that many firms are part of global value chains (GVCs) and, thus, international input-output linkages are necessary to assess the effects of trade costs on competitiveness, they use information on trade in value added to feed a computable general equilibrium model (based on the Global Trade Analysis Project) that yields a measure of the impact of import tariffs on Italian exports. They document substantial heterogeneity in the effect of the common EU trade policy across countries, sectors and firms, and the importance of the manufacturing sector in explaining the results, despite low levels of nominal 
protection. The impact of tariffs depends on the share of imported inputs and also on the geography of GVCs: for instance, the current tariff schedule entails higher costs for Italian producers relative to German ones, while the former are posed to gain more from (bilateral) trade agreements that reduce trade barriers on imported inputs.

Cirera, Lederman, Máñez Castillejo, Rochina Barrachina and Sanchis Llopis ("Firm productivity gains in a period of slow trade liberalization: evidence from Brazil") study the relationship between firms' trade status, tariff reductions and productivity. They focus on a period of slow liberalization, as the one experienced by Brazil from 2000 to 2008, and show that, despite the modest changes in trade policy, there was a positive impact of trade liberalization on firm-level productivity, with output and input tariffs working through different channels. They find that, while a reduction in output tariffs contributes to a small degree to productivity growth by increasing import competition that forces firms to improve efficiency, productivity growth mainly occurs thanks to a reduction in import tariffs that allows firms to access (cheaper or better) foreign intermediate inputs. In fact, they document also the presence of spillover effects to non-importing firms that extend the benefits of trade liberalization beyond the group of agents directly affected by the policy. Following these findings, the authors suggest that Brazil has more room for a deepening of trade liberalization, especially in intermediate goods, and that this can lead to further improvements in firms' productivity.

Finally, Giovannetti, Marvasi and Vivoli ("The asymmetric effects of twenty years of tariff reforms on Egyptian workers") look at the long run effect of trade policy on the labour market, following the evolution of tariff reforms in Egypt over the last 20 years. Interestingly, this period is marked by a policy reversal whereby the initial liberalization of the late 1990s has made way for a tightening of trade restrictions at least since 2016 following the 2008 financial crisis and 2011 Spring revolution and the subsequent government change. Such tariff changes have remarkable asymmetric effects. On the one hand, higher protection of the domestic market is associated with a worsening in labour market conditions, both in terms of real wages and the probability of finding a stable job in the formal economy. On the other hand, they also show that reductions in trade barriers have only minor positive effects on Egyptian workers. Thus, the authors suggest that protectionist measures have failed to protect workers and even a few years of protectionism can lead to a significant deterioration of labour market conditions. However, the aggregate results hide important sources of heterogeneity between different types of workers in different sectors and this heterogeneity has implications for wage inequality. In particular, the authors show that protectionism contributes to increase inequality, which may have further long-run negative effects on labour markets.

\section{References}

Amiti, M., Redding, S. J., \& Weinstein, D. E. (2019). The impact of the 2018 tariffs on prices and welfare. Journal of Economic Perspectives, 33(4), 187-210. 
Amiti, M., Redding, S. J., \& Weinstein, D. E. (2020). Who's paying for the US tariffs? A longer-term perspective. AEA Papers and Proceedings, 110, 541-546.

Autor, D., Dorn, D., Hanson, G., \& Majlesi, K. (2020). Importing political polarization? The electoral consequences of rising trade exposure. American Economic Review, 110(10), 3139-3183. https:// doi.org/10.1257/aer.20170011.

Baldwin, R. E. (2016). The great convergence: information technology and the new globalization. Cambridge: The Belknap Press of Harvard University Press.

Bloom, N., Draca, M., \& Van Reenen, J. (2016). Trade induced technical change? The impact of Chinese imports on innovation, IT and productivity. The Review of Economic Studies, 83(1), 87-117. https://doi.org/10.1093/restud/rdv039.

Bown, C. (2020). How Trump's export curbs on semiconductors and equipment hurt the US technology sector. Trade and Investment Policy Watch, Peterson Institute for International Economics, 28 September 2020

Bown, C. P., \& Keynes, S. (2020). Why trump shot the sheriffs: the end of WTO dispute settlement 1.0. Journal of Policy Modeling, 42(4), 799-819.

Caselli, M. (2018). Do all imports matter for productivity? Intermediate inputs vs capital goods. Economia Politica: Journal of Analytical and Institutional Economics, 35(2), 285-311. https://doi. org/10.1007/s40888-017-0071-5.

Caselli, M., Fracasso, A., \& Traverso, S. (2020a). Globalization and electoral outcomes: evidence from Italy. Economics and Politics, 32, 68-103. https://doi.org/10.1111/ecpo.12147.

Caselli, M., Fracasso, A., \& Traverso, S. (2020b). Globalization, robotization and electoral outcomes: evidence from spatial regressions for Italy. Journal of Regional Science, Forthcoming. https:// doi.org/10.1111/jors.12503.

Caselli, M., Nesta, L., \& Schiavo, S. (2021). Imports and labour market imperfections: firm-level evidence from France. European Economic Review, 131, 103632. https://doi.org/10.1016/j.euroe corev.2020.103632.

Caselli, M., \& Schiavo, S. (2020). Markups, import competition and exporting. The World Economy, 43(5), 1309-1326. https://doi.org/10.1111/twec.12935.

Cohen, H. G. (2020). Nations and markets. Journal of International Economic Law, 23(4), $793-815$. https://doi.org/10.1093/jiel/jgaa032.

Colantone, I., \& Stanig, P. (2018a). Global competition and brexit. American Political Science Review, 112(2), 201-218. https://doi.org/10.1017/S0003055417000685.

Colantone, I., \& Stanig, P. (2018b). The trade origins of economic nationalism: import competition and voting behavior in Western Europe. American Journal of Political Science, 62(4), 936-953. https://doi.org/10.1111/ajps.12358.

Evenett, S. J. (2019). Protectionism, state discrimination, and international business since the onset of the global financial crisis. Journal of International Business Policy, 2, 9-36. https://doi. org/10.1057/s42214-019-00021-0.

González, A., Froman, M., \& Bown, C. (2020). What trade policy priorities for the Biden administration? Trade Winds, Peterson Institute for International Economics, 18 November 2020. https:// www.piie.com/events/what-trade-policy-priorities-biden-administration

Harrison, J., Barbu, M., Campling, L., Ebert, F. C., Martens, D., Marx, A., et al. (2019). Labour standards provisions in EU free trade agreements: reflections on the European commission's reform agenda. World Trade Review, 18(4), 635-657. https://doi.org/10.1017/S14747456180002 04.

Iacovone, L., Rauch, F., \& Winters, L. A. (2013). Trade as an engine of creative destruction: Mexican experience with Chinese competition. Journal of International Economics, 89(2), 379-392. https ://doi.org/10.1016/j.jinteco.2012.09.002.

Nordhaus, W. D. (2015). Climate clubs: overcoming free-riding in international climate policy. American Economic Review, 105(4), 1339-1370. https://doi.org/10.1257/aer.15000001.

Pauwelyn, J. (2020). "Export restrictions in times of pandemic: options and limits under international trade agreements", 54. Journal of World Trade, 5, 727-747.

Prazeres, T. L. (2020). Trade and national security: rising risks for the WTO. World Trade Review, 19(1), 137-148. https://doi.org/10.1017/S1474745619000417.

Prusa, T. J. (2005). Anti-dumping: a growing problem in international trade. The World Economy, 28(5), 683-700. https://doi.org/10.1111/j.1467-9701.2005.00700.x. 
Utar, H. (2014). When the floodgates open: 'northern' firms' response to removal of trade quotas on Chinese good. American Economic Journal: Applied Economics, 6(4), 226-250. https://doi. org/10.1257/app.6.4.226.

von der Leyen, U. (2019). A Union that strives for more. My agenda for Europe. Political Guidelines for the next European Commission 2019-2024. https://ec.europa.eu/commission/sites/beta-political/ files/political-guidelines-next-commission_en.pdf

Publisher's Note Springer Nature remains neutral with regard to jurisdictional claims in published maps and institutional affiliations. 